\title{
Adult demography, spatial distribution and movements of Zerynthia polyxena (Lepidoptera: Papilionidae) in a dense network of permanent habitats
}

\author{
TATJANA ČELIK \\ Jovan Hadži Institute of Biology, Scientific Research Centre of the Slovenian Academy of Sciences and Arts, Novi trg 2, \\ P.O. Box 306, SI-1001 Ljubljana, Slovenia; e-mail: tcelik@zrc-sazu.si
}

\begin{abstract}
Key words. Lepidoptera, Papilionidae, Zerynthia polyxena, Southern Festoon, mark-release-recapture, demography, resource distribution, movement, home range, butterfly conservation
\end{abstract}

\begin{abstract}
The adult demographic parameters, mobility, nectar choice and how the spatial distribution of males and females of $Z$. polyxena is affected by the distribution and abundance of host-plants, and adults of the opposite sex was studied in a population of this species inhabiting a dense network of permanent habitats (totalling $8.7 \mathrm{ha}$ ). The population size was estimated to be ca. 300 individuals. The average adult lifespan was 4.4 days and the maximum 23 (male) and 20 (female) days. The capture probability was higher for males than females due to the more conspicuous behaviour and bounded area of activity of males. A slow increase was followed by a slow decrease in the sex specific parabolic recruitment curve, indicating slight protandry and long emergence period, probably due to habitat heterogeneity. The spatial distribution of host plants (Aristolochia lutea) is the key factor determining the spatial distribution of adults. There was a strong positive correlation between male and female density at each patch, both of which were dependent on the cover of host plants growing in sunny conditions. In searching for A. lutea plants suitable for oviposition, females fly greater distances and move more frequently between patches than males. The size, shape and orientation of the male home range were influenced by the size, shape and orientation of stands of host-plants in sunny positions, but not by patch area. Such adult fidelity to stands of host-plants in sunny positions indicates that the spatial distributions of oviposition sites, matelocating sites and larval habitats of $Z$. polyxena overlap. The better statistical fit and much lower probabilities for long-distance movements generated by a negative exponential function than an inverse power function are probably due to the small size and high habitat connectivity of the site studied. Adults were opportunistic in their use of nectar plants. Traditional management is the key factor for maintaining permanent habitats for this species in a grassland biotope.
\end{abstract}

\section{INTRODUCTION}

The Southern Festoon, Zerynthia polyxena (Dennis \& Schiffermüller, 1775) (Lepidoptera: Papilionidae), is listed in the Habitats Directive 92/43 EEC of the European Union. In the European Red List of Butterflies (Van Swaay et al., 2010) it is classified as of Least Concern (LC) because it has declined by less than $30 \%$ over the last 10 years. However, this Red List assessment should be taken as a conservative estimate of threat because a comparison of detailed monitoring data for some butterfly species has shown that population trends strongly underestimate extinction risks (Van Sway et al., 2011).

Although $Z$. polyxena is legally protected there is little precise information on this butterfly's biology and population ecology. Since the different life stages of butterflies have different resource requirements, detailed ecological studies of each stage are needed in order to define a species' requirements in terms of the functional resourcebased concept (Dennis, 2003). As the availability of resources for adults affects their behaviour (e.g., Turlure \& Van Dyck, 2009; Ide, 2010), spatial distribution (e.g., Loertscher et al., 1995; Krauss et al., 2005), movements (e.g., Brommer \& Fred, 1999; Schneider et al., 2003) and demographic parameters (e.g., Luoto et al., 2001; Auckland et al., 2004; Junker \& Schmitt, 2010), it is important to have a good knowledge of adult ecology when designing an appropriate management policy for the long- term survival of a target species. Since $Z$. polyxena utilizes the same plant species (Aristolochia spp.) for oviposition and as a host plant (e.g., Höttinger, 2003; Batáry et al., 2008; Puissauve, 2009), it is expected that the oviposition and larval habitats will overlap spatially.

The role of feeding resources for adults of $Z$. polyxena is questionable as authors have different views. According to Habeler (1986), Hesselbarth et al. (1995) and Puissauve (2009), Z. polyxena is opportunistic in its use of nectar plants. In the Mediterranean region the adults also feed on animal dung (Habeler, 1986). However, Baumann (1981) and Höttinger (2003) report that adults of this species do not feed on nectar in Austria, which is at northern limit of this species'distribution and as a consequence they assume that flower richness in or in the vicinity of larval habitats is not important for $Z$. polyxena in Austria (Höttinger, 2003).

Z. polyxena inhabits a wide range of biotopes in Europe (Van Sway et al., 2006), including ruderal habitats (e.g., Konvička, 2002; Höttinger, 2003). At a landscape scale, its habitats can differ in terms of fragmentation (fragmented vs. continuous), configuration (linear vs. nonlinear) and stability (temporary vs. permanent). Variation in the spatial and temporal arrangement of habitats in a landscape could be reflected in different life-history traits, as has been shown for many butterfly species: (i) habitat fragmentation affects demographic parameters (Brück- 
man et al., 2011), adult movements (Mennechez et al., 2003; Schtickzelle et al., 2006; Wang et al., 2011), mate location behaviour (Merckx \& Van Dyck, 2005) and genetic structure of populations (Vandewoestijne \& Baguette, 2004); (ii) linear elements of habitats within a landscape promote movements (Pryke \& Samways, 2001; Nowicki et al., 2005) and those functioning as corridors also facilitate dispersal (Haddad, 1999) and increase gene flow between connected patches (Vandewoestijne et al., 2004); (iii) habitat stability has an effect on adult mobility (Scott, 1975; Bergman \& Landin, 2002) and avoidance of parasitoids (Ohsaki \& Sato, 1990). It is also important from this point of view to have a knowledge of the ecology of adults of $Z$. polyxena in different types of landscape.

In this paper, I present the results of a one-season investigation of an adult population of $Z$. polyxena within a region in which the distribution of this species was continuous. The aim of the study was (1) to estimate the demographic parameters, movements and home ranges of adults in a dense network of predominantly permanent habitats, (2) to analyze how the spatial distribution of males and females is affected by the distribution and abundance of host-plants and adults of the opposite sex and (3) to identify the range of feeding resources used by adults.

\section{MATERIAL AND METHODS}

\section{Study species}

Z. polyxena is distributed from SE France through Italy and the southern part of Central Europe to the Balkans and Asia Minor (Tolman \& Lewington, 1997). The flight period lasts from March to late June, depending on location and weather conditions (Hesselbarth et al., 1995; Höttinger, 2003). In Europe, Z. polyxena inhabits sparse deciduous woods, orchards, vineyards, scrub, wet and dry grassland, rocky steppes and ruderal habitats (e.g., Habeler, 1986; Konvička, 2002; Batáry et al., 2008; Puissauve, 2009). Larvae develop on plants of the genus Aristolochia L. (Aristolochiaceae) (cf. Nazari \& Carbonell, 2006). In Slovenia, A. clematitis Linnaeus, A. pallida Willdenow and $A$. lutea Desfontaines are used as host plants (Špiljar, 2007; Verovnik et al., 2009; Čelik, 2010a, b). The females emerge with most of their eggs already mature (Baumann, 1981; Van Helsdingen et al., 1996). They usually lay single or small batches of eggs on the undersides of leaves, rarely on other parts of the host plant (e.g., Beer, 1946; Batáry et al., 2008; Puissauve, 2009). Z. polyxena hibernates as pupa on plant stems, twigs or the underside of stones (Tolman \& Lewington, 1997), rarely on the underside of leaves of the host plant (Höttinger, 2003).

\section{Study area}

The study site is located in south-western Slovenia $\left(45^{\circ} 38^{\prime} \mathrm{N}\right.$, $14^{\circ} 0^{\prime} \mathrm{E}$, altitude $400 \mathrm{~m}$ ), in the flysch Brkini region. It is in a bounded area situated in the flat bed of the Sušica stream valley which consists of a mosaic of traditionally maintained hay meadows, orchards and hedges. The study site is spread along a $1.2 \mathrm{~km}$ length of the valley, which extends $0.8 \mathrm{~km}$ and $1.6 \mathrm{~km}$ further towards the north and the south-east, respectively (Fig. 1). It mainly comprises extensively used dry, semi-dry and mesophilous non-fertilized hay meadows, mostly surrounded by hedges on one side and forest slopes on the other. These meadows are managed by mowing once or twice a year with

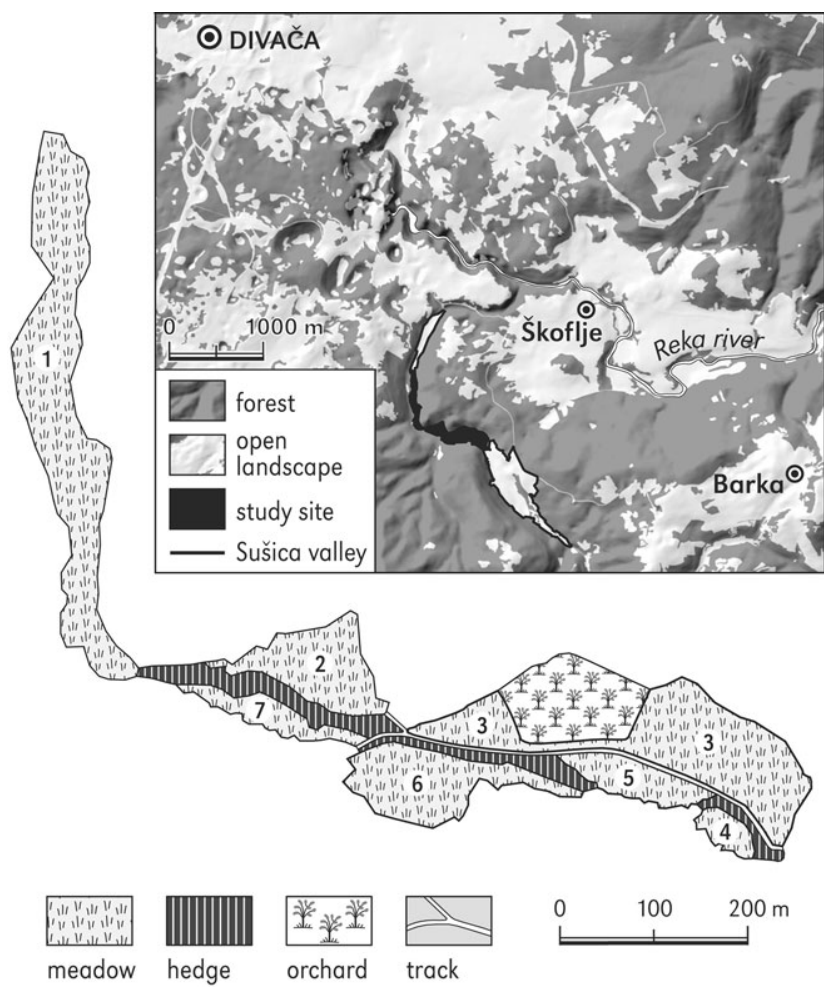

Fig. 1. Map of the site where the MRR study of Zerynthia polyxena was carried out in SW Slovenia in 2009. The habitat patches studied are marked with numbers 1-7.

some parts on steeper slopes temporarily left uncut. The study site was subdivided into seven patches (total $8.7 \mathrm{ha}$ ), based on prominent landmarks (hedges, cart tracks) or changes in the structure of the vegetation (forest slopes). The southern part of patch no. 6 is a recently abandoned dry meadow.

\section{Mark-release-recapture (MRR)}

The MRR study was conducted from 11 April to 21 May 2009. Each day, weather permitting, all 7 patches were visited; the time spent within each patch was proportional to its size. On the last day of sampling, nine adults were still present but unsuitable weather prevented further sampling sessions. Butterflies were netted and marked with an individual number on the underside of the left fore-wing using a thin-pointed permanent pen and immediately released at the location of their capture. The following data was recorded before release: individual number, sex, GPS position of capture point (Garmin GPSmap $60 \mathrm{CSx}$ with precision of $\pm 3 \mathrm{~m}$ ), date and hour.

Because the habitat was contiguous throughout the area, the MRR data from all 7 patches were pooled (separately for both sexes) for the analysis of demographic parameters. The constrained linear model (CLM) methodology (Lebreton et al., 1992; Schtickzelle et al., 2003) in the MARK v.5.1 program was used (Cooch \& White, 2008; White, 2008). The POPAN formulation incorporated in the MARK program allows the estimation of three primary parameters: survival probability ( $\Phi$; combining mortality and emigration), capture probability $(p)$ and probability of entering the population (i.e., proportional recruitment, pent; combining births and immigration). These parameters may be constant $(\bullet)$, dependent on sex $(g)$, respond to time in a factorial $(t)$, linear $(t l i n)$ or quadratic $\left(t l i n+t l^{2} n^{2}\right)$ manner, or display additive or interactive interactions. The parameters derived using the POPAN formulation are the daily number of births $\left(B_{i}\right)$, daily population size $\left(N_{i}\right)$ and total population size $\left(N_{t o t}\right)$. 
The best model was selected from a set of candidate models using Aikaike's Information Criterion corrected for small sample size $\left(A I C_{c}\right)$ (Burnham \& Anderson, 2002) in a two-step procedure as suggested by Schtickzelle et al. (2002). First, 64 Cormack-Jolly-Seber (CJS) models defining the responses of $\Phi$ and $p$ to sex and time were derived. Secondly, the best CJS models were used to construct Jolly-Seber (JS) models incorporating eight basic structures $(g, t, t$ lin, $g+t, g+t l i n, g \times t, g \times$ tlin, $\bullet$ ) and 3 additional for pent $\left(t l i n+t^{2}{ }^{2}, g+t l i n+t l i n^{2}, g x\right.$ $\left[\right.$ tlin $\left.\left.+t^{\prime i n^{2}}\right]\right)$. From the best supported JS models (i.e., models with $\triangle A I C_{c}<2$ ) the best model for inference was chosen using the principle of parsimony.

The average daily survival is a weighted mean of the POPAN daily values, weights being the number of captures on a given day. Three sample occasions (date: $15^{\text {th }}$ April, $4^{\text {th }}$ and $7^{\text {th }}$ May) were excluded from this calculation because of the large confidence limits for the POPAN daily values. The average lifetime expectancy was calculated as $-\ln$ (average daily survival) ${ }^{-1}$ (Cook et al., 1967).

A non-parametric Kolmogorov-Smirnov $Z$ test was used to analyse the difference in observed lifetime between sexes. The $\chi^{2}$ test for homogeneity was applied for testing the departure of the sex ratio of captures/recaptures from 1:1. Both tests were performed using SPSS 13.0 (SPSS Inc., 1989-2004).

\section{Host and nectar plants}

A. lutea is the only species of Aristolochia in the study area. The size of the stands of the host-plant ranged from 2 to 3610 $\mathrm{m}^{2}$ (median: $250 \mathrm{~m}^{2}, n=21$ ). They were distributed mainly in abandoned or extensively managed meadows, along hedges and occasionally at the edges of forest. The main axis of all large stands $\left(\geq 100 \mathrm{~m}^{2}, n=14\right)$ was elongated mostly in the same direction as the main axis of the corresponding patch. Three categories of host-plant cover were used: "TOTAL A. lutea $\left(\mathrm{m}^{2}\right)$ " is the sum of all host-plant stands in a patch, "SUNNY $A$. lutea $\left(\mathrm{m}^{2}\right)$ " is the area of host plant stands growing in predominantly sunny positions during the whole flight period. This excludes stands or parts of stands that were only exposed to the sun at the beginning of the flight period (i.e., before the trees produced leaves in spring). "SUNNY A. lutea (\%)" is the percentage of the patch size made up of stands of the host plant growing in sunny conditions.

During the flight period of $Z$. polyxena, forty-three flowering species of herbaceous plants were recorded in the study area. Their abundances were scored in four classes: rare, occasional, frequent and common. Of the 43 species 22 were rare, 9 occasional, 4 frequent (Globularia punctata Linnaeus, Lathyrus linifolius Bässler, Salvia pratensis Linnaeus, Viola rivininana Reichebach) and 8 common (Orchis morio Linnaeus, Potentilla alba Linnaeus, Pulmonaria officinalis Linnaeus, Taraxacum erythrospermum Besser, Veronica chamaedrys Linnaeus, Vicia cracca agg., Viola canina Linnaeus s. lat., Viola hirta Linnaeus) species. The following data were recorded for the nectar sources of adults: plant species, GPS location of nectar plant and the hour observed feeding. Observations on feeding were conducted between 9.30 and 18.00 CEST.

\section{Spatial distribution of adults}

The spatial distribution of adults was determined in two ways. First, the dependence of captures of adults on patch characteristics was analysed by constructing multiple regression models. Pearson's correlation coefficients between the following variables were calculated as a first step: (i) demographic parameters, such as the number and density of captures within a patch (separately for the two sexes), and (ii) patch characteristics such as patch size, TOTAL A. lutea $\left(\mathrm{m}^{2}\right)$, SUNNY A. lutea $\left(\mathrm{m}^{2}\right)$ and
SUNNY A. lutea (\%). All variables were log-transformed to approximate a normal distribution. The effect of patch characteristics and the demographic parameter of one sex on the demographic parameter of the opposite sex was then tested by hierarchical multiple regression. The variable showing the strongest correlation with the demographic parameter as a dependent variable was entered into the model first (blockwise entry) then all the other explanatory variables were entered in a second step using stepwise procedure. Since the density of males captures showed a significant and almost equally strong correlation with two variables, two models with the density of males captures as the dependent variable were constructed.

Secondly, the dependence of number of captures on the distance to the nearest stand of the host-plant growing in sunny site was calculated separately for the two sexes. Captures at such sunny sites or at a distance less than $10 \mathrm{~m}$ from one were classified in the distance class " 0 ". In total there were fourteen 10 meter distance classes. As there were very few captures at distances greater than $50 \mathrm{~m}$ the number of captures at distances between 50 and $140 \mathrm{~m}$ were pooled into one class $(>50 \mathrm{~m})$ for testing the dependence between sex and distance to the nearest sunny site with a stand of host-plants using the $\chi^{2}$ test for association.

\section{Mobility}

The mobility of adults was estimated separately for the two sexes using three parameters: distance between consecutive captures $(D)$, index of home range and home range (calculated only for males due to an insufficient number of females that were each captured at least 3 times).

The distance between consecutive captures was measured as a straight line connecting two consecutive points of capture. For all adults captured more than once, the distances were pooled in $50 \mathrm{~m}$ classes, separately for each sex. A negative-exponential function (NEF) and an inverse-power function (IPF) (Hill et al., 1996) were used to assess the probabilities of movements to distances beyond those covered by the MRR study. The probability $(P)$ of an individual moving a certain distance $(D)$ is:

$$
P_{\mathrm{NEF}}=a \mathrm{e}^{-k D}, P_{\mathrm{IPF}}=a D^{-n}
$$

The parameters $a, k$ and $n$ were estimated by regressing the natural logarithms of inverse cumulative proportions of individuals moving $50 \mathrm{~m}$ distance classes $(\ln P)$ on distances (in $\mathrm{km}$ ) in NEF [i.e., $\ln (P)=\ln (a)-k(D)$ ], and on natural logarithms of distances (in km) in IPF [i.e., $\ln (P)=\ln (a)-n \ln (D)$ ]. The slopes $(k, n)$ of the resulting fitted distributions were compared using $t$-tests in regression (UCLA ATS, 2007).

The maximum distance between capture points of an individual (observed range length) was used as an index of home range.

The area, shape and orientation of the home ranges of males were estimated by the method of Mazurkiewicz, as explained by Randolph (1977). Two categories of males were defined for further analysis: individuals observed only in one patch and individuals that moved between patches during their lifetime, herein referred to as Sedentary and Dispersive males, respectively. The shape of the home ranges was calculated as the ratio of the major to minor axis of the ellipse, which is the measure of departure from a round shape (i.e., elongation rate of the ellipse). The angles of orientation of the ellipses with respect to the $\mathrm{x}$-axis of the map grid were grouped into $30^{\circ}$ segments and the number of individuals in each segment counted. Three types of segments were used in further calculations: $\left|0-30^{\circ}\right|$, $\left|31-60^{\circ}\right|$ and $\left|61-90^{\circ}\right|$.

A non-parametric Mann-Whitney test was used to analyse the difference in the mobility of the sexes and different categories 


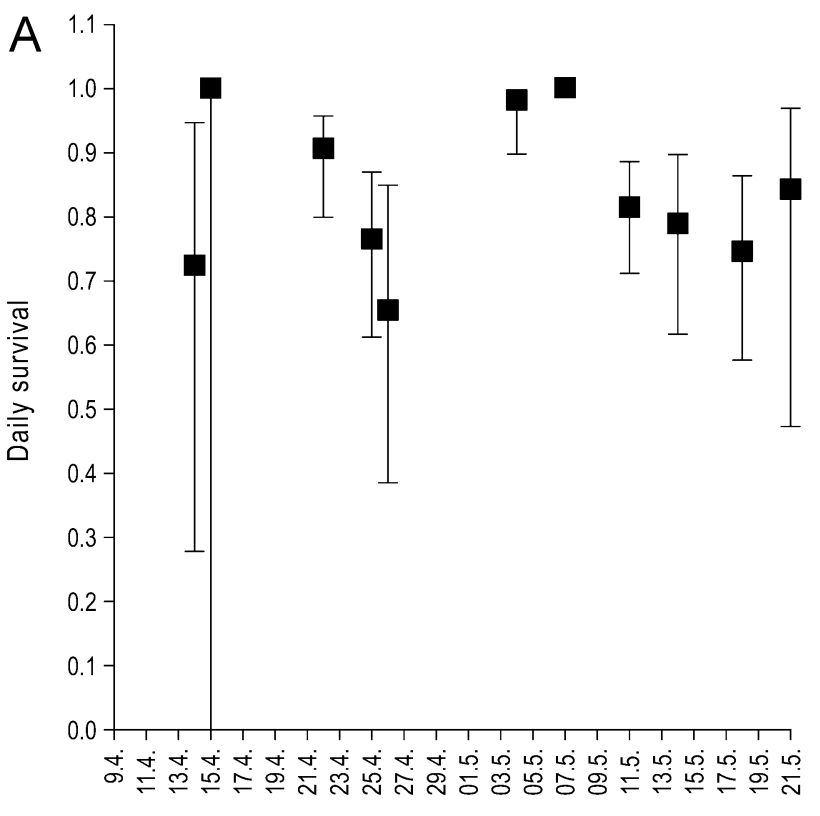

Date

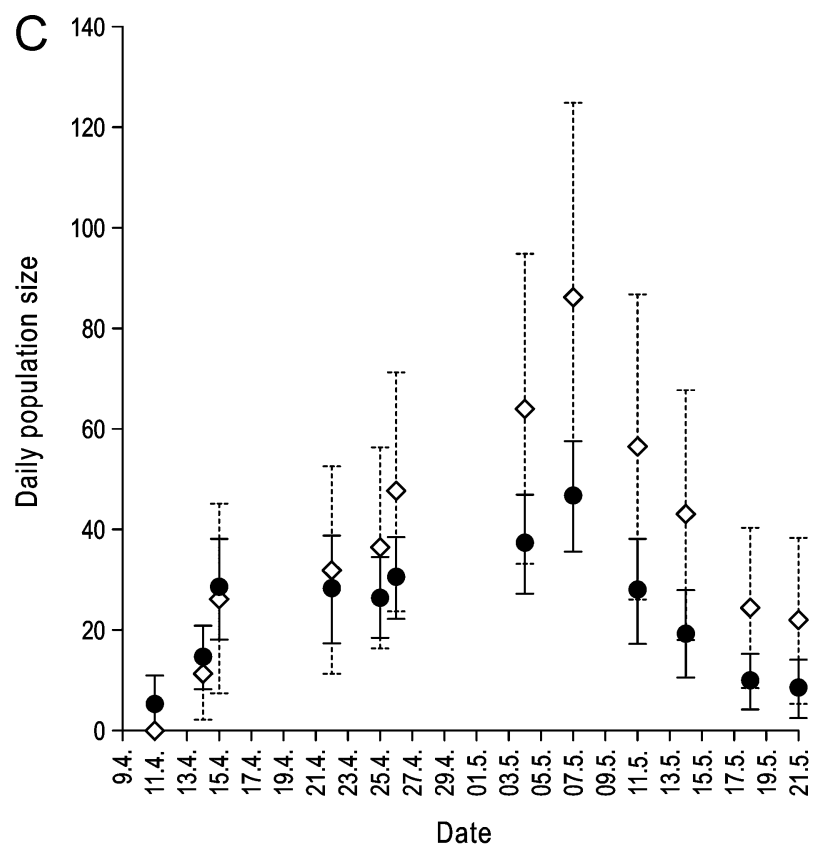

of males. The $\chi^{2}$ test for independence was applied to test the association between sex and distances moved between patches. The $\chi^{2}$ test for homogeneity was used for analysing the preferred orientation of home ranges. A non-parametric correlation coefficient, Kendall's $\tau$, was chosen due to the small data set with tied ranks, to analyse the relationship between the home range size and patch area. For Dispersive males, all patches within their home range were included in the calculation of patch area. For Sedentary males, Kendall's $\tau$ was used to calcu-

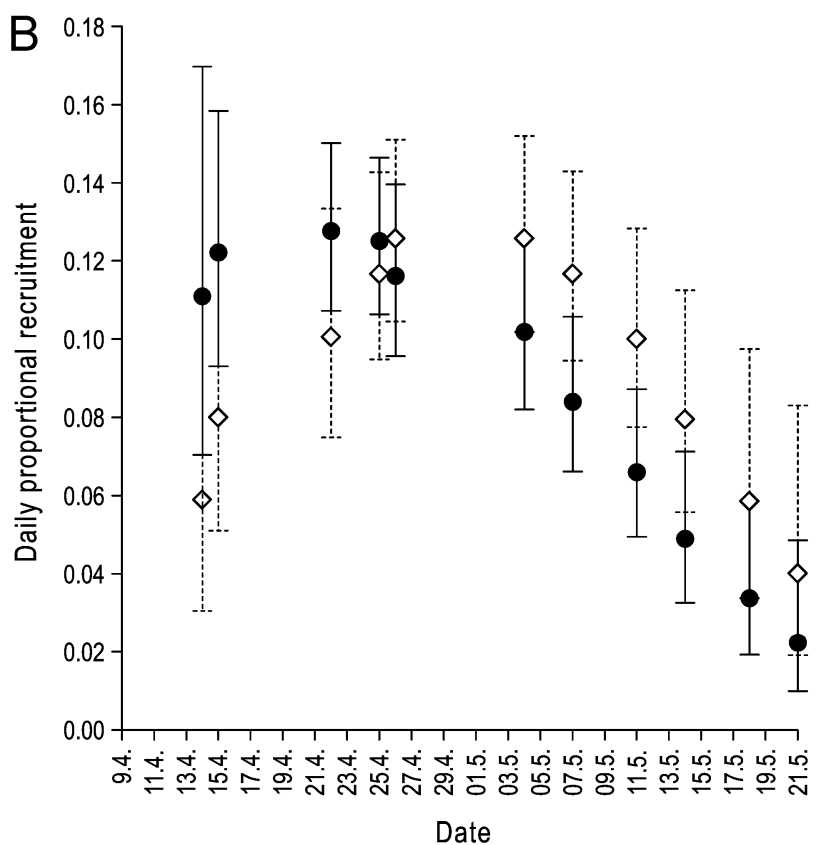

Fig. 2. A - Estimates of the daily survival of Zerynthia polyxena in SW Slovenia in 2009, using the best supported model in the POPAN module in the MARK program. The error lines represent $95 \%$ confidence intervals. Black squares represent males and females. B - Estimates of the daily proportional recruitment of Zerynthia polyxena in SW Slovenia in 2009, using the best supported model in the POPAN module in the MARK program. The error lines represent $95 \%$ confidence intervals. Black circles represent males, open diamonds females. $\mathrm{C}$ - Estimates of the daily population size of Zerynthia polyxena in SW Slovenia in 2009, using the best supported model in the POPAN module in the MARK program. The error lines present $95 \%$ confidence intervals. Black circles represent males and open diamonds females.

late the correlation between the home range size and area of host-plant stands in sunny sites within that patch. All statistical analyses were performed using SPSS 13.0 (SPSS Inc., 1989-2004).

\section{RESULTS}

\section{Demographic parameters}

In total, 162 individuals (males: 88 , females: 74) were marked and $74(46 \%)$ of them were recaptured (Table 1$)$.

TABLE 1. Summary of the MRR data used to determine the demography of Zerynthia polyxena in SW Slovenia in 2009.

\begin{tabular}{lcccc}
\hline & No. of marked individuals & No. (\%) of recaptured individuals & No. of captures & No.(\%) of recaptures \\
\hline Males & 88 & $52(59)$ & 185 & $97(52)$ \\
Females & 74 & $22(30)$ & 101 & $27(27)$ \\
Total & 162 & $74(46)$ & 286 & 124 \\
\hline
\end{tabular}


The sex ratio of captures was male biased $\left(\chi^{2}=24.08\right.$, d.f. $=1, P<0.001)$, and males were recaptured more often than females $\left(\chi^{2}=38.40\right.$, d.f. $\left.=1, P<0.001\right)$.

Both candidate Jolly-Seber models (Table 2) indicated that survival varied between days with no particular pattern, that catchability differed between sexes and that the recruitment rate followed a sex specific parabola, with the probability of entering the population increasing at the beginning of the flight period and decreasing at the end.

Using the best model (Table 2), the estimated parameters showed that (1) daily survival, which was not sex specific (Fig. 2a), was on average (mean with 95\% CI) $0.80(0.75-0.85)$, corresponding to an average lifetime expectancy of 4.4 (3.4-6.0) days; (2) catchability (mean with $95 \% \mathrm{CI})$ of males was significantly higher $(0.58$, $0.46-0.68)$ than of females $(0.21,0.12-0.34)$; (3) peak of male emergence was 4 days earlier than that of females (Fig. 2b); (4) the survey period did not include the end of the female flight season (Fig. 2c) and females outnumbered males only on day 12 of the flight season and on day 27 both populations peaked, with an estimated population density of 5 males/ha and 10 females/ha; (5) total population density was 13 males/ha and 22 females/ha.

The observed lifetime was significantly longer for males (median: 2 days, 1st and 3rd quartiles: 1 and 8 days, max: 23 days) than for females (median, 1st and 3rd quartiles: all 1 day, max: 20 days) (Kolmogorov-Smirnov $Z=2.03, P<0.01)$.

\section{Nectar sources}

On thirty-three occasions adults of both sexes were observed feeding on nectar from a total of 18 species of plants (Fig. 3), which corresponds to $42 \%$ of all the flowering species of herbaceous plants in the study area. They included $7(88 \%)$ common, $3(75 \%)$ frequent, $3(33 \%)$ occasional and $5(23 \%)$ rare species. All the nectar plants occurred together with the host plants. Adults were observed feeding on nectar between 10.00 and 17.30 CEST with more than half (55\%) of them before 12.00 CEST and $88 \%$ before 16.00 CEST.

\section{Spatial distribution of host plants and adults}

The areas of host plant stands in sunny positions varied from 250 to $4185 \mathrm{~m}^{2}$ (Table 3), corresponding to $2-58 \%$ of the total patch area. For both sexes, the strongest positive correlation was observed between the density of captures and percentage cover of host plants in sunny sites within a patch (Table 4). There was also a strong positive relationship between the density of captures of males and females within a patch (Table 4).

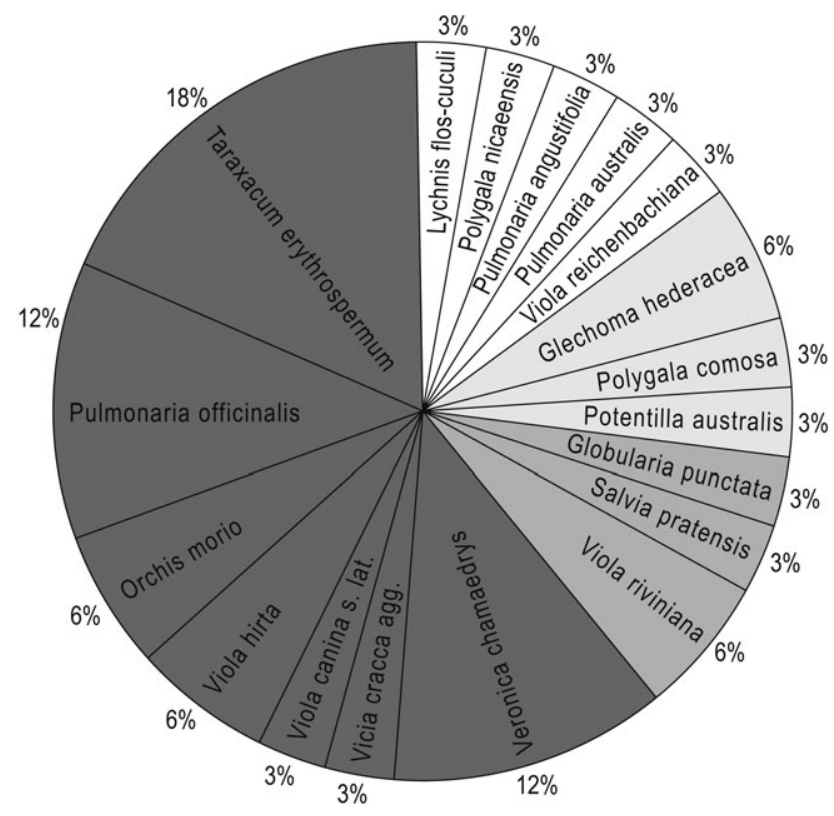

rare

occasional

frequent

common

Fig. 3. Range of plants used as sources of nectar by adults of Zerynthia polyxena, recorded during the MRR study in SW Slovenia in 2009. The percentages are based on 33 observations of adults feeding on nectar. The abundance of different nectar plants in the study area is colour coded as either rare, occasional, frequent or common.

The variation in the percentage cover of host plants in sunny sites accounted for $93 \%$ of variation in the density of female captures within a patch (Table 5: Model 1). Inclusion of the area of a patch significantly (by 5\%) improved the model with constant and percentage cover of host plants in sunny sites as the first predictor (Table 5: Model 2). The $66 \%$ variation in the density of male captures in a patch can be accounted for when the percentage cover of host plants in sunny sites within a patch is used as the first predictor (Table 5: Model 1a). Because of the strong positive relationship between this explanatory variable and the density of female captures, the latter was not included in Model 1a as a predictor. When the density of female captures was used as the first predictor in the model, it accounted for $65 \%$ of the variation in the density of male captures within a patch (Table 5: Model 1b). Other explanatory variables were excluded from both models.

TABLE 2. The best supported Jolly-Seber models and estimates of the total population size of Zerynthia polyxena in SW Slovenia in 2009. All models with $\triangle A I C_{c}<2$ are shown. The best model is in bold.

\begin{tabular}{|c|c|c|c|c|c|c|}
\hline Models & $\triangle A I C_{c}$ & np & $N_{t o t} \widehat{\partial} \pm \mathrm{SE}$ & $N_{t o t}+ \pm \mathrm{SE}$ & $95 \%$ CI ठิ & $95 \%$ CI우 \\
\hline$\Phi(t) p\left(g^{*} t\right) b\left(g+t_{l i n}+t_{l i n^{2}}\right) N(g)$ & 0.00 & 33 & $104 \pm 8$ & $203 \pm 47$ & $95-130$ & $139-332$ \\
\hline$\Phi(t) p(g) b\left(g *\left[t l i n+t_{l i n}^{2}\right]\right) N(g)$ & 0.63 & 17 & $112 \pm 8$ & $189 \pm 41$ & $101-133$ & $132-300$ \\
\hline
\end{tabular}

$\triangle A I C_{c}$ - the difference in the value of the Akaike's Information Criterion, $\mathrm{np}$ - number of parameters, $N_{t o t} \hat{0} \pm \mathrm{SE}$ - estimated population size of males, $N_{\text {tot }} \uparrow \pm \mathrm{SE}-$ estimated population size of females, $95 \%$ CI $\hat{\sigma}-95 \%$ confidence interval for estimated population size of males, $95 \% \mathrm{CI}$ - $95 \%$ confidence interval for estimated population size of females. 
TABLE 3. Summary of the data used for determining the spatial distribution of adults of Zerynthia polyxena in seven habitat patches in SW Slovenia in 2009. See Material and methods for an explanation of the parameters.

\begin{tabular}{|c|c|c|c|c|c|c|c|c|}
\hline \multirow{2}{*}{ Patch } & \multirow{2}{*}{$\begin{array}{l}\text { Patch size } \\
\text { (ha) }\end{array}$} & \multirow{2}{*}{$\begin{array}{c}\text { TOTAL } \\
\text { A. lutea }\left(\mathrm{m}^{2}\right)\end{array}$} & \multirow{2}{*}{$\begin{array}{c}\text { SUNNY } \\
\text { A. lutea }\left(\mathrm{m}^{2}\right)\end{array}$} & \multirow{2}{*}{$\begin{array}{c}\text { SUNNY } \\
\text { A. lutea }(\%)\end{array}$} & \multicolumn{2}{|c|}{ No. of captures } & \multicolumn{2}{|c|}{ Density of captures $\left(\mathrm{ha}^{-1}\right)$} \\
\hline & & & & & $\hat{0}$ & q & $\hat{0}$ & 우 \\
\hline 1 & 2.96 & 3070 & 760 & 3 & 24 & 16 & 8 & 5 \\
\hline 2 & 0.97 & 2262 & 512 & 5 & 13 & 12 & 13 & 12 \\
\hline 3 & 2.50 & 677 & 477 & 2 & 29 & 10 & 12 & 4 \\
\hline 4 & 0.20 & 500 & 450 & 22 & 19 & 6 & 95 & 30 \\
\hline 5 & 0.52 & 3000 & 3000 & 58 & 16 & 23 & 31 & 45 \\
\hline 6 & 1.11 & 4310 & 4185 & 38 & 75 & 29 & 67 & 26 \\
\hline 7 & 0.41 & 1000 & 250 & 6 & 6 & 5 & 15 & 12 \\
\hline
\end{tabular}

TABLE 4. Correlation matrix of the number and density of captures, patch area, total host plant cover and host plant cover in sunny places of the habitat patch for Zerynthia polyxena in SW Slovenia in 2009. The correlation coeficients are shown in the top right hand part and $P$ values at the bottom of the table. See Material and methods for an explanation of the parameters.

\begin{tabular}{|c|c|c|c|c|c|c|c|c|}
\hline & $\begin{array}{c}\text { No. of } \\
\text { captures } q\end{array}$ & $\begin{array}{c}\text { No. of } \\
\text { captures } \sigma^{\star}\end{array}$ & $\begin{array}{l}\text { Density of } \\
\text { captures } q\end{array}$ & $\begin{array}{l}\text { Density of } \\
\text { captures } \delta\end{array}$ & Patch area & $\begin{array}{l}\text { TOTAL } A . \\
\text { lutea }\left(\mathrm{m}^{2}\right)\end{array}$ & $\begin{array}{l}\text { SUNNY } A \text {. } \\
\text { lutea }\left(\mathrm{m}^{2}\right)\end{array}$ & $\begin{array}{c}\text { SUNNY } A . \\
\text { lutea }(\%)\end{array}$ \\
\hline No. of captures 9 & & 0.689 & 0.236 & 0.093 & 0.450 & $0.863 *$ & $0.925 * *$ & 0.423 \\
\hline No. of captures $\widehat{\delta}$ & 0.087 & & 0.028 & 0.366 & 0.441 & 0.370 & 0.678 & 0.235 \\
\hline Density of captures & 0.611 & 0.953 & & $0.806 *$ & $-0.761 *$ & 0.193 & 0.535 & $0.965 * * *$ \\
\hline Density of captures $\widehat{\sigma}$ & 0.843 & 0.419 & 0.029 & & -0.673 & -0.112 & 0.420 & $0.815^{*}$ \\
\hline Patch area & 0.311 & 0.322 & 0.047 & 0.097 & & 0.389 & 0.128 & -0.604 \\
\hline TOTAL $A$. lutea $\left(\mathrm{m}^{2}\right)$ & 0.012 & 0.414 & 0.679 & 0.811 & 0.389 & & 0.744 & 0.320 \\
\hline SUNNY A. lutea $\left(\mathrm{m}^{2}\right)$ & 0.003 & 0.094 & 0.216 & 0.348 & 0.784 & 0.055 & & 0.713 \\
\hline SUNNY A. lutea $(\%)$ & 0.344 & 0.613 & 0.000 & 0.026 & 0.151 & 0.484 & 0.072 & \\
\hline
\end{tabular}

$* P<0.05, * * P<0.01, * * * P<0.001$.

The spatial distribution of captures indicates that the majority of adults were recorded on host-plants growing in sunny conditions (Fig. 4): $77 \%$ of the male captures and $63 \%$ of female captures were obtained on stands of host-plants in sunny positions and an additional 10\% and $23 \%$ were recorded between 10 and $20 \mathrm{~m}$ from such stands. Only in the distance class $10-20 \mathrm{~m}$ were significantly more female captures than expected (i.e., an individual component of $\chi^{2}=4.49$ ) but the association between sex and the minimum distance from host-plant stand in sunny position was not significant $\left(\chi^{2}=10.27\right.$, d.f. $=5, P>0.06)$.

\section{Mobility}

Females moved between patches more frequently than males $\left(\chi^{2}=5.62\right.$, d.f. $\left.=1, P<0.05\right)$. Most of the interpatch movements (males: 84\%, females: 75\%) were between adjacent patches. Females covered greater distances (median: $90 \mathrm{~m}$ ) between consecutive captures than males (median: $45 \mathrm{~m}$ ) (Mann-Whitney $z=-3.87, P<$ $0.001)$. The index of home range was significantly higher for females (median: $106 \mathrm{~m}$ ) than for males (median: 59 m) (Mann-Whitney $z=-2.54, P<0.05$ ). The maximum observed range of both sexes (males: $400 \mathrm{~m}$, females: 406 m) was estimated to be $30 \%$ of the maximum possible

TABLE 5. Hierarchical multiple regression of the density of captures as a dependent variable (log-transformed) for Zerynthia polyxena in seven habitat patches in SW Slovenia in 2009. Other variables from Table 4 were used as predictors.

\begin{tabular}{|c|c|c|c|c|c|c|c|}
\hline Sex & Variable & $R^{2}$ & $F$ & $\mathrm{df}$ & $P$ & $t$ & $P$ \\
\hline \multirow{7}{*}{ q } & Model 1 & 0.932 & 68.172 & 1,5 & 0.000 & & \\
\hline & Constant & & & & & -38.482 & 0.000 \\
\hline & $\log _{10}$ SUNNY A. lutea $(\%)$ & & & & & 8.257 & 0.000 \\
\hline & Model 2 & 0.982 & 108.039 & 1,4 & 0.000 & & \\
\hline & Constant & & & & & -6.743 & 0.003 \\
\hline & $\log _{10}$ SUNNY A. lutea $(\%)$ & & & & & 9.412 & 0.001 \\
\hline & $\log _{10}$ patch area & & & & & -3.322 & 0.029 \\
\hline \multirow{6}{*}{ 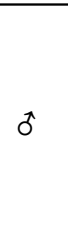 } & Model 1a & 0.663 & 9.857 & 1,5 & 0.026 & & \\
\hline & Constant & & & & & -15.374 & 0.000 \\
\hline & $\log _{10}$ SUNNY A. lutea $(\%)$ & & & & & 3.140 & 0.026 \\
\hline & Model 1b & & & & & & \\
\hline & Constant & 0.650 & 9.286 & 1,5 & 0.029 & -0.339 & 0.749 \\
\hline & $\log _{10}$ density of $q$ captures & & & & & 3.047 & 0.029 \\
\hline
\end{tabular}




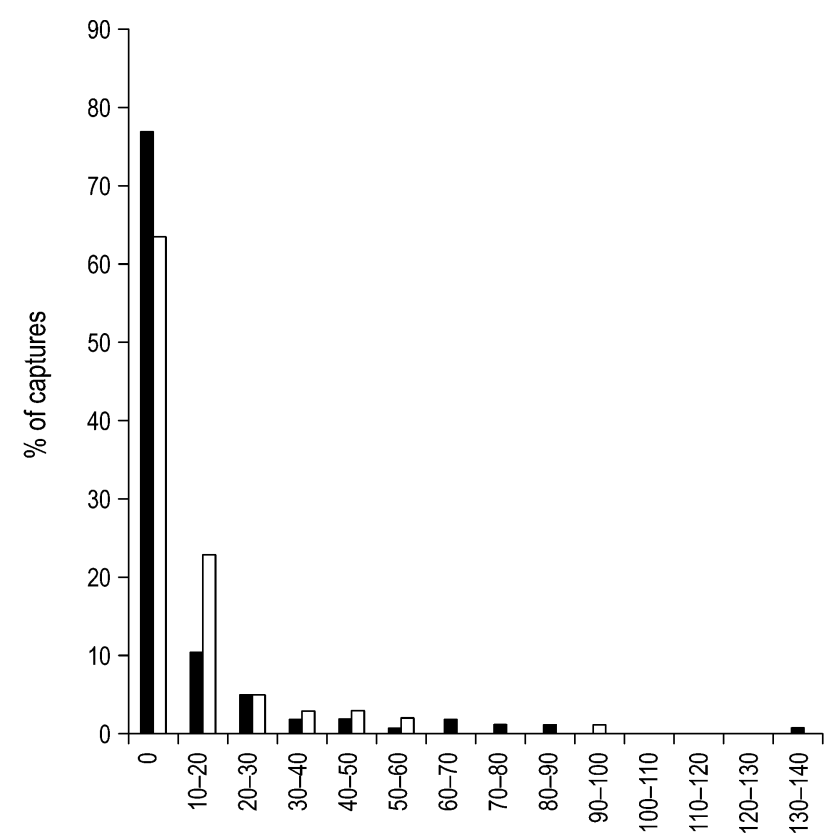

Distance to the nearest sunny host-plant stand $(m)$

Fig. 4. Dependence of the distribution of captures of Zerynthia polyxena on the distance to the nearest stand of host plants growing in a sunny site in SW Slovenia in 2009. Black bars represent males $(n=185)$, white bars females $(n=101)$.

range (i.e., the distance between the furthest points in the study area, passing across habitat patches).

Fitting NEF to the mobility data resulted in the following equations, $\ln (P)=-0.18( \pm 0.099 \mathrm{SE})-12.38( \pm$ $0.474 \mathrm{SE}) D$ for males and $\ln (P)=0.16( \pm 0.131 \mathrm{SE})$ $-8.73( \pm 0.574 \mathrm{SE}) D$ for females. The fit was highly significant for both males $(F=682.93$, d.f. $=1,7, P<0.001$, $\left.R^{2}=0.99\right)$ and females $(F=254.86, d . f .=1,7, P<0.001$, $\left.R^{2}=0.97\right)$. The slope was significantly $(t=4.85$, d.f. $=$ $16, P<0.001)$ steeper for males. Fitting IPF to the same data resulted in the equations $\ln (P)=-3.95( \pm 0.537 \mathrm{SE})$ $-0.66( \pm 0.178 \mathrm{SE}) \ln (D)$ for males and $\ln (P)=-2.69( \pm$ $0.463 \mathrm{SE})-0.49( \pm 0.162 \mathrm{SE}) \ln (D)$ for females. The fits were again significant (males: $F=13.71$, d.f. $=1,7, P<$ 0.05, $R^{2}=0.67$; females: $F=9.00$, d.f. $=1,7, P<0.05, R^{2}$ $=0.56)$. The regression slopes did not differ $(t=0.72, d$.f. $=16, P>0.4)$. Using the above equations, NEF predicted a lower probability of movement over distances greater than $0.3 \mathrm{~km}$ (Fig. 5). The estimated probabilities of longdistance movements using NEF were $3.5210^{-6}$ (males) and $1.9010^{-4}$ (females) for $1 \mathrm{~km}, 1.1010^{-27}$ (males) and $1.3110^{-19}$ (females) for $5 \mathrm{~km}$ and $1.4410^{-54}$ (males) and $1.4610^{-38}$ (females) for $10 \mathrm{~km}$. For the same distances, IPF predicted dispersal probabilities of 0.019 (males) and 0.068 (females), 0.007 (males) and 0.031 (females), and 0.004 (males) and 0.022 (females). The predictions of the average distances moved by individuals were $81 \mathrm{~m}(\mathrm{NEF})$ vs. $1513 \mathrm{~m}$ (IPF) for males and $115 \mathrm{~m}$ (NEF) vs. $2054 \mathrm{~m}$ (IPF) for females.

The home range size of males varied between 4 and $12232 \mathrm{~m}^{2}$ (median: $1719 \mathrm{~m}^{2}$, 1st and 3rd quartiles: 398 and $7693 \mathrm{~m}^{2}$ ). There was no correlation between the

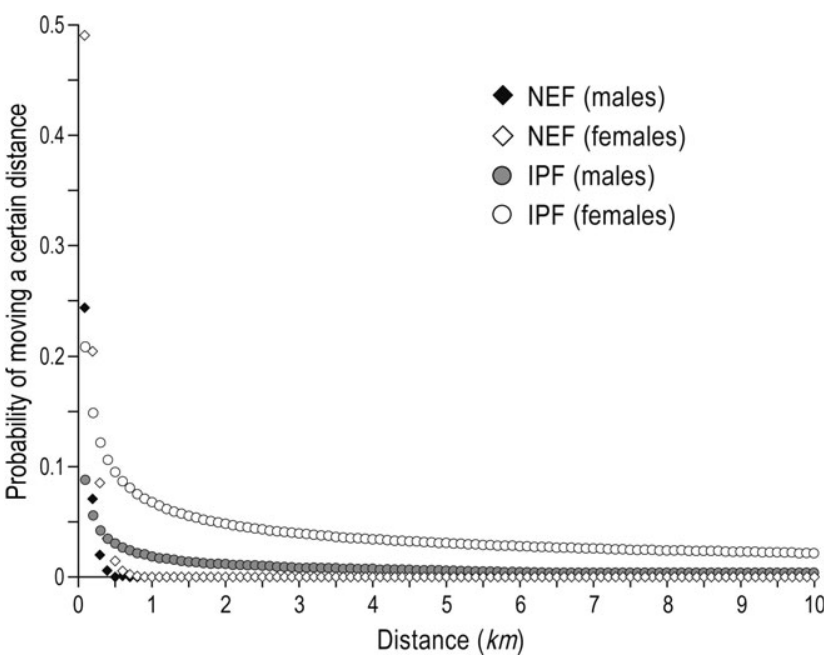

Fig. 5. The probability of moving a certain distance generated by the negative exponential function (NEF) and inverse power function (IPF) equations for all adults of $Z$. polyxena captured more than once in SW Slovenia in 2009.

home range size and patch area for either category of males (Sedentary, $n=15$ : Kendall $\tau=-0.179, P>0.3$; Dispersive, $n=12$ : Kendall $\tau=0.208, P>0.3)$. The home range size of Sedentary males correlated positively with the area of host-plant stands growing in sunny positions within a patch (Kendall $\tau=0.432, P<0.05$ ). The home range was elongated and significantly different from a round shape $\left(\chi^{2}=25.03\right.$, d.f. $\left.=1, P<0.001\right)$. There was no difference in average elongation rate of the ellipses of the two categories of males (Sedentary, median = 5.66; Dispersive, median $=5.86$; Mann-Whitney $z=$ $-0.59, P>0.5)$. The majority of males $(n=16)$ aligned their home ranges within the segment $\left|0-30^{\circ}\right|$ of the $\mathrm{x}$-axis of the map grid $\left(\chi^{2}=10.89\right.$, d.f. $\left.=2, P<0.01\right)$. There was no difference in average elongation rate of the ellipses for males in orientation class $\left|0-30^{\circ}\right|$ (median $=$ $5.23)$ and those in orientation class $\left|31-90^{\circ}\right|($ median $=$ 8.03) (Mann-Whitney $z=-0.35, P>0.7$ ).

\section{DISCUSSION}

\section{Demography}

The demographic pattern indicated by both candidate JS models, i.e. a higher male catchability, a protandrous recruitment and a hump-shaped pattern in daily population size, is similar to that recorded for other univoltine butterflies (e.g., Baguette \& Schtickzelle, 2003; Fric et al., 2010). The factorial response of daily survival (and catchability indicated by the supported JS model) to time points to an effect of daily differences in weather (cf. Schtickzelle et al., 2002). The most likely reason for the higher capture probability of males is the difference in activity of the sexes. Males are more conspicuous due to their mate-locating behaviour, which alternates between patrolling and perching (Van Helsdingen et al., 1996). Estimated mobility also indicates that males are active within smaller areas than females and are strongly associated with suitable host-plant stands, and hence more 
detectable than females. The spatially limited lifetime activity of males also resulted in a longer observed average lifespan. The observed maximum lifetime of both sexes are supported by the observations of Špiljar (2007) and Beer (1946).

Although sampling ceased before the last females ceased flying, the flight-period was 41 days, which is at least 21, 10 and 5 days longer than that reported in Hungary (Batáry et al., 2008), NE Slovenia (Špiljar, 2007) and France (Puissauve, 2009), respectively. Since the start and length of the flight period may be influenced by weather conditions (Zimmermann et al., 2011a), size of the population (chance effects) and habitat heterogeneity (Hanski \& Gilpin, 1997, and references therein) this may simply reflect the influence of one or more of these parameters.

The estimated population density of 35 individuals/ha was four times higher than that recorded in a small and isolated population in central Slovenia and is probably one of the highest for $Z$. polyxena in this country (Verovnik et al., 2009). Together with other demographic characteristics of the population studied, this suggests that a dense network of permanent habitats contributes to a relatively high population density and, consequently, probably better population stability.

\section{Spatial distribution and mobility}

Results from regression models suggest that the spatial distribution of host plants (A. lutea) is the key factor determining the spatial distribution of adults of $Z$. polyxena. The adult population density in a patch is determined by the percentage cover of $A$. lutea growing in sunny positions within a patch. The distributions of males, females and host plants in sunny sites overlapped widely. The finding that females exceeded males in all the mobility parameters estimated, with a significant positive correlation between the number of female captures and the host-plant cover in sunny sites within a patch, can be explained by (i) a bet-hedging strategy of ovipositing females (cf. Janz et al., 2005), i.e. spreading their eggs over a large area, and/or (ii) an active search by receptive females for mates, if they actively solicit mating (cf. Hesselbarth et al., 1995). The lower values of practically all the mobility indices for males indicate that, on average, males spent a large part of their life in a single small area. The size, shape and orientation of male home ranges are largely determined by the size, shape and orientation of host-plant stands in sunny positions. This enables males to keep a large area of host plants under surveillance and, consequently, to maximize encounters with receptive females.

According to some authors (e.g., Weidemann, 1995; Dapporto, 2010), Z. polyxena is a sedentary species. In contrast, Höttinger (2003) assumes that these butterflies are more mobile, i.e., capable of dispersal over distances of more than $10 \mathrm{~km}$, especially along linear landscape elements. Such mobility enables them to follow changes in the distribution of host plants colonizing ephemeral habitats. However, recent studies on butterflies reveal that long distance dispersal occurs even in species once con- sidered sedentary (Zimmermann et al., 2011b) and that MRR-derived dispersal estimates are highly variable at the species level (Stevens et al., 2010), suggesting that within-species variability may be enhanced by variation in weather conditions and/or landscape connectivity (cf. Schtickzelle et al., 2006). In our study, the marking within a bounded area limited chances of detecting possible long-distance flights. Despite the size of the study area influencing the MRR-observed distances moved (Schneider, 2003) and, consequently, estimated dispersal probabilities (Kuras et al., 2003), the observed mobility parameters recorded for Z. polyxena suggest that within a dense network of habitats, this species is not very mobile. Namely, the maximum observed range length of both sexes covered only $30 \%$ of the distance between the furthest points in the study area. However, the probability of long-distance movements predicted by the IPF indicates that this species is more mobile: based on the estimated population sizes of both sexes, approximately 4 female per generation should disperse up to $10 \mathrm{~km}$, while the longest possible male movement was estimated to be 3 $\mathrm{km}$. Considering the prediction of the equation for the better-fitting NEF, though, dispersal up to $10 \mathrm{~km}$ would be highly unlikely (males: $2 \times 10^{-52}$, females: $3 \times 10^{-36}$ ); the longest predicted possible flights per generation were 0.4 $\mathrm{km}$ (males) and $0.7 \mathrm{~km}$ (females). According to the distribution data (Čelik, 2004; Verovnik et al., 2009), $Z$. polyxena occurs throughout the Sušica valley and then from its northern end, where the valley broadens into an open landscape, several kilometres further towards the north-west and south-east (cf. Fig. 1). Considering the size of the population studied and that the distribution area is large and contiguous, it is likely that the population structure of this species within this area has the form of an interconnected system. As long-distance movements in butterflies might be of a different nature than withinsite movements (Baguette, 2003; Kuras et al., 2003), the most likely reason for the discrepancy between the predictions of long-distance movements of $Z$. polyxena generated by NEF and IPF, and between both functions in statistical fits, is the small size of the area studied and high habitat connectivity within it (cf. Schneider, 2003).

Since many studies of different animal species have shown clear evidence of plasticity in dispersal distances of a species (Wiens, 2001), it is possible that the dispersal ability of $Z$. polyxena is different in different types of landscapes. The effect of landscape configuration on the dispersal distances of butterflies is well established (Fric et al., 2010) and is also reported for beetles depending on ephemeral resources (Roslin, 2000). Considering these findings and the fact that the NEF and IPF equations are based on movements recorded within a bounded area without effective barriers, long-distance movements of $Z$. polyxena in other types of landscape are quite likely. The effects of landscape fragmentation, configuration and patch age on movement distance (cf. Hanski et al., 2002; Ovaskinen et al., 2008) of this species await further research. 


\section{Range of nectar sources}

Records on nectar sources of adults obtained in this study and those of earlier authors (Habeler, 1986; Hesselbarth et al., 1995; Puissauve, 2009), suggest that $Z$. polyxena is an opportunist feeder. The lack of nectar records from the northern border of this species distribution (Höttinger, 2003) might reflect a lack of flowering plants there during the flight period in spring. Opportunistic flower use by $Z$. polyxena might be explained by the findings of Stefanescu \& Traveset (2009), who postulated that the degree of generalization in flower use is (i) affected by phylogeny, with Papilionidae showing an intermediate level of generalization, (ii) positively related to the length of the flight period and habitat openness, and (iii) negatively related to degree of larval polyphagy.

\section{Conclusions and conservation implications}

Z. polyxena is a monophagous species linked to a single plant genus (Aristolochia sp.), which is the important factor determining the species' geographical distribution and spatial population structure. Since Aristolochia plants are fairly patchily distributed, this butterfly displays a colonial distribution (Dapporto, 2010), often limited to sites covering only a few square metres in which the host plant occur (Konvička, 2002; Čelik, 2010a, b). In such a situation, a metapopulation dynamics is expectable.

Host plants growing in sunny sites are essential for $Z$. polyxena. The spatial distribution of host-plant stands in sunny positions is the main factor determining the spatial distribution of adults, resulting in a high degree of overlap between adult and larval habitats. Since the species is also capable of inhabiting sites where host plants cover only a few square metres, the maintenance and even promotion of host-plant stands in ephemeral habitats (e.g., river embankments, railway ridges, roadsides, track ridges, abandoned arable fields) could contribute to species persistence in a fragmented landscape. These host plant stands could act as stepping-stones or as corridors between patches if corridors are limited to linear landscape elements, which are supposed to facilitate the dispersion of adults (cf. Höttinger, 2003).

The mainly continuous distribution of $Z$. polyxena in the study area demonstrates that traditional management, without applying fertilizer and mowing only once or twice a year, is a key factor in maintaining a more or less permanent habitat for this species in a landscape in which host plants are distributed mainly in meadows and along surrounding hedges. In addition, general threats such as the application of pesticides in nearby farmland, early spring fires, afforestation, urbanization and spread of invasive plant species, should be taken into account (Van Helsdingen, 1996; Konvička, 2002; Höttinger, 2003; Čelik, 2010a, b).

This study basically demonstrates that the preservation of suitable larval host plants is essential for Z. polyxena. The main conservation focus should be directed at the identification and conservation of such host plants in a suitable spatial arrangement. Data on mobility indicate that this might be different in different biotopes and/or structured landscapes.

ACKNOWLEDGMENTS. I am very grateful to M. Dolek for valuable comments on the manuscript. I thank C. van Sway for providing detailed information on Z. polyxena from the database for the European Red List of Butterflies, B. Vreš for the identification of some of the nectar plants, I. Sajko for making the map (Fig. 1) and anonymous referees for suggestions that greatly improved the manuscript. This research was funded by the Slovenian Research Agency (P1-0236) and the Ministry of Environment and Spatial Planning of the Republic of Slovenia (2511-10-250021).

\section{REFERENCES}

Auckland J.N., Debinski D.M. \& Clark W.R. 2004: Survival, movement, and resource use of the butterfly Parnassius clodius. Ecol. Entomol. 29: 139-149.

BAGUETTE M. 2003: Long distance dispersal and landscape occupancy in a metapopulation of the cranberry fritillary butterfly. Ecography 26: 153-160.

Baguette M. \& Schtickzelle N. 2003: Local population dynamics are important to conservation of metapopulations in highly fragmented landscape. J. Appl. Ecol. 40: 404-412.

BAUMANN E. 1981: Erfolgreiche Wiedereinbürgerung von Zerynthia polyxena auf einem ehemaligen Weinberg am Stadtrand von Graz. Beih. Veröff. Natursch. Landschaftspfl. Bad.-Württ. 21: 177-179.

Batáry P., Örvössy N., Körösi A. \& Peregovits L. 2008: Egg distribution of the southern festoon (Zerynthia polyxena) (Lepidoptera, Papilionidae). Acta Zool. Acad. Sci. Hung. 54: 401-410.

BeER S. 1946: Ricerche sulla biologia di Zerynthia hypsipyle Schulze. Mem. Soc. Entomol. It. 25: 34-73.

Bergman K.O. \& Landin J. 2002: Population structure and movements of threatened butterfly (Lopinga achine) in a fragmented landscape in Sweden. Biol. Conserv. 108: 361-369.

Brommer J.E. \& Fred M.S. 1999: Movement of the Apollo butterfly Parnassius apollo related to host plant and nectar plant patches. Ecol. Entomol. 24: 125-131.

Brückman S.V., Krauss J., van Achterberg C. \& SteffanDEWENTER I. 2011: The impact of habitat fragmentation on trophic interactions of the monophagous butterfly Polyommatus coridon. J. Insect Conserv. 15: 707-714.

Burnham K.P. \& Anderson D.R. 2002: Model Selection and Multimodel Inference. A Practical Information - Theoretic Approach. Springer, New York, 488 pp.

Cooch E. \& White G. 2008: Program MARK. "A Gentle Introduction", $7^{\text {th }}$ ed.

http://www.phidot.org/software/mark/docs/book

Cook L.M., Brower L.P. \& Croze H.J. 1967: The accuracy of a population estimation from multiple recapture data. J. Anim. Ecol. 36: 57-60.

ČELIK T. 2004: Diverziteta dnevnih metuljev (Lepidoptera: Rhopalocera) v Regijskem parku Škocjanske jame. [Diversity of butterfly fauna (Lepidoptera: Rhopalocera) in the Škocjanske jame Regional park. Acta Biol. Sloven. 47: 95-111 [in Slovene].

ČELIK T. 2010a: Conservation assessment of the butterfly fauna along the River Sava between Krško and the state border. Acta Biol. Sloven. 53: 71-97.

ČELIK T. 2010b: An inventory of butterfly fauna and habitats along the River Sava between Litija and Zidani most. In Govedič M., Grobelnik V. \& Lešnik A. (eds): An Inventory of Animal and Plant Species and Habitat Types with Regard to 
the Species of Community Interest, Ecologically Important Areas and Protected Areas along the River Sava between Hydroelectric Power Station Medvode and Hydroelectric Power Station Vrhovo. Center za kartografijo favne in flore, Miklavž na Dravskem polju, pp. 211-292 [in Slovene].

DAPPORTO L. 2010: Speciation in Mediterranean refugia and post-glacial expansion of Zerynthia polyxena (Lepidoptera, Papilionidae). J. Zool. Syst. Evol. Res. 48: 229-237.

DENNIS R.L.H. 2003: Towards a functional resource-based concept for habitat: a butterfly biology viewpoint. Oikos 102: $417-426$

Fric Z., Hula V., Klímová M., Zimmermann K. \& KonvičKa M. 2010: Dispersal of four fritillary butterflies within identical landscape. Ecol. Res. 25: 543-552.

Habeler H. 1986: Zur Kenntnis der Lebensräume des Osterluzeifalters, Zerynthia polyxena (Denis \& Schiffermuller, 1775). Mitt. Abt. Zool. Landesmus. Joanneum 39: 221-223.

HADDAD N.M. 1999: Corridor and distance effects on interpatch movements: a landscape experiment with butterflies. Ecol. Appl. 9: 612-622.

HANSKi I.A. \& Gilpin M.E. 1997: Metapopulation Biology. Ecology, Genetics, and Evolution. Academic Press, San Diego, $512 \mathrm{pp}$.

Hanski I., Breuker C.J., Schops K., Setchfield R. \& Nieminen M. 2002: Population history and life history influence the migration rate of female Glanville fritillary butterflies. Oikos 98: 87-97.

Hesselbarth G., Van Oorschot H. \& Wagener S. 1995: Die Tagfalter der Türkei. Band I. Selbstverlag Sigbert Wagener, Bocholt, 754 pp.

HiLl J.K., Thomas C.D. \& Lewis O.T. 1996: Effects of habitat patch size and isolation on dispersal by Hesperia comma butterflies: implications for metapopulation structure. J. Anim. Ecol. 65: 725-735.

HÖtTINGER H. 2003: Neue Erkenntnisse zu Verbreitung, Ökologie und Gefährdung des Osterluzeifalters Zerynthia polyxena (Denis \& Schiffermüller, 1775) in Österreich mit besonderer Berücksichtigung des Burgenlandes (Lepidoptera: Papilionidae). Beitr. Entomofaun. 4: 89-105.

IDE J. 2010: Weather factors affecting the male mate-locating tactics of the small copper butterfly (Lepidoptera: Lycaenidae). Eur. J. Entomol. 107: 369-376.

JANZ N., Bergström A. \& Johansson J. 2005: Frequency dependence of host plant choice within and between patches: a large cage experiment. Evol. Ecol. 19: 289-302.

Junker M. \& Sсhмitт T. 2010: Demography, dispersal and movement pattern of Euphydryas aurinia (Lepidoptera: Nymphalidae) at the Iberian Peninsula: an alarming example in an increasingly fragmented landscape? J. Insect Conserv. 14: 237-246.

KonvIČKA M. 2002: Pestrokřídlec podražcový (Zerynthia polyxena). In Beneš J. \& Konvička M. (eds): [Butterflies of the Czeck Republic: Distribution and Conservation I.] SOM, Prague, pp. 156-158.

Krauss J., Steffan-Dewenter I., Müller B. \& Tscharntke T. 2005: Relative importance of resource quantity, isolation and habitat quality for lanscape distribution of monophagous butterfly. Ecography 28: 465-474.

Kuras T., Beneš J., Fric Z. \& KonvičKa M. 2003: Dispersal patterns of endmic alpine butterflies with contrasting population structures: Erebia epiphron and E. sudetica. Popul. Ecol. 45: $115-123$.

Lebreton J.D., Burnham K.P., Clobert J. \& Anderson D.R. 1992: Modelling survival and testing biological hypotheses using marked animals - a unified approach with case studies. Ecol. Monogr. 62: 67-118.
Loertscher M., ERhardt A. \& Zettel J. 1995: Microdistribution of butterflies in a mosaic-like habitat. The role of nectar sources. Ecography 18: 15-26.

Luoto M., Kuussaari M., Salminen J. \& von Bonsdorff T. 2001: Determinants of distribution and abundance in the clouded apollo butterfly: a landscape ecological approach. Ecography 24: 601-617.

Mennenchez G., Schtickzelle N. \& Baguette M. 2003: Metapopulation dynamics of the bog frittilary butterfly: comparison of demographic parameters and dispersal between a continuous and highly fragmented landscape. Landscape Ecol. 18: 279-291.

Merckx T. \& VAN Dyck H. 2005: Mate location behaviour of the butterfly Pararge aegeria in woodland and fragmented landscapes. Anim. Behav. 70: 411-416.

NAZARI V. \& CARbonell F. 2006: Zerynthia polyxena (Denis and Schiffermüller, 1775). Version 07 July 2006 (under construction). http://tolweb.org/Zerynthia_polyxena

Nowicki P., Witek M., Skorka P., Settele J. \& Woyciechowski M. 2005: Population ecology of the endangered butterflies Maculinea teleius and M. nausithous and the implications for conservation. Popul. Ecol. 47: 193-202.

Ohsaki N. \& Sato Y. 1990: Avoidance mechanisms of three Pieris butterfly species against the parasitoid wasp Apanteles glomerulus. Ecol. Entomol. 15: 169-176.

Ovaskinen O., Smith A.D., Osborne J.L., Reynolds D.R., CarRECK N.L., Martin A.P., NiITEPöld K. \& HANSKi I. 2008: Tracking butterfly movements with harmonic radar reveals an effect of population age on movement distance. PNAS 108: 19090-19095.

Pryke S.R. \& SAmways M.J. 2001: Width of grassland linkages for the conservation of butterflies in South African afforested areas. Biol. Conserv. 101: 85-96.

Puissauve R. 2009: La Diane Zerynthia polyxena Denis and Schiffermüller, 1775 (Lepidoptera: Papilionidae) et son habitat dans la plaine de Pompignan (France, Gard): Définition d'un protocole d'étude standardisé. Rapport de stage de Master 1 en Ingénierie en Ecologie et en Gestion de la Biodiversité, Université Montpellier, 62 pp.

RANDOLPH S.E. 1977: Changing spatial relationships in a population of Apodemus sylvaticus with the onset of breeding. $J$. Anim. Ecol. 46: 653-676.

Rosuin T. 2000: Dung beetle movements at two spatial scales. Oikos 91: 323-335.

SCHNEIDER C. 2003: The influence of spatial scale on quantifying insect dispersal: an analysis of butterfly data. Ecol. Entomol. 28: $252-256$

SchNeider C., Dover J. \& Fry G.L.A. 2003: Movement of two grassland butterflies in the same habitat network: the role of adult resources and size of the study area. Ecol. Entomol. 28: 219-227.

Schtickzelle N., Boulengé E.L. \& Baguette M. 2002: Metapopulation dynamics of the bog fritillary butterfly: demographic processes in a patchy population. Oikos 97: 349-360.

Schtickzelle N., Baguette M. \& Le Boulengé E. 2003: Modelling insect demography from capture-recapture data: comparison between the constrained linear models and the JollySeber analytical method. Can. Entomol. 135: 313-323.

Schtickzelle N., Mennechez G. \& Baguette M. 2006: Dispersal depression with habitat fragmentation in the bog fritillary butterfly. Ecology 87: 1057-1065.

Sсотт J.A. 1975: Flight patterns among eleven species of diurnal Lepidoptera. Ecology 56: 1367-1377.

SPSS INC. 1989-2004: SPSS for Windows. Release 13.0 (1 Sep 2004). 
Stefanescu C. \& Traveset A. 2009: Factors influencing the degree of generalization in flower use by Mediterranean butterflies. Oikos 118: 1109-1117.

Stevens V.M., Turlure C. \& Baguette M. 2010: A metaanalysis of dispersal in butterflies. Biol. Rev. 85: 625-642.

ŠPILJAR A. 2007: Ekološke raziskave populacije ogrožene vrste metulja petelinčka Zerynthia polyxena (Denis \& Schiffermüller, 1775) (Lepidoptera) na območju Konjišča ob Muri. [Ecological Researches of Threatened Butterfly Zerynthia polyxena (Denis \& Schiffermüller, 1775) (Lepidoptera) at Konjišče on River Mura.] Thesis, Maribor University, 70 pp. [in Slovene].

Tolman T. \& Lewington R. 1997: Butterflies of Britain and Europe. Harper Collins, London, 320 pp.

TurluRe C. \& VAN Dyck H. 2009: On the consequences of aggressive male mate-locating behaviour and micro-climate for female host plant use in the butterfly Lycaena hippothoe. Behav. Ecol. Sociobiol. 63: 1581-1591.

UCLA ATS 2007: Statistical Computing. UCLA: Academic Technology Services, Statistical Consulting Group. http://www.ats.ucla.edu/stat/spss/topics/regression.htm

Van Helsdingen P.J., Willemse L. \& Speight M.C.D. 1996: Background Information on Inverterbrates of the Habitats Directive and the Bern Convention. Nature and Environment No. 79. Council of Europe, Strasbourg, 217 pp.

Van Swaay C.A.M., Warren M.S. \& LoÏs G. 2006: Biotope use and trends of European butterflies. J. Insect Conserv. 10: 189-209.

Van Swahy C.A.M, Cuttelod A., Collins S., Maes D., Munguira López M., Šašić M., Settele J., Verovnik R., Verstrael T., Warren M., Wiemers M. \& Wynhof I. 2010: European Red List of Butterfies. Publications Office of the European Union, Luxembourg, $46 \mathrm{pp}$.

Van Swaay C.A.M., Maes D., Collins S., Munguira Lopez M., Šs šić M., Settele J., Verovinik R., Warren M., Wiemers M., Wynhof I. \& Cuttelod A. 2011: Applying IUCN criteria to invertebrates: How red is the Red List of European butterflies? Biol. Conserv. 144: 470-478.

Vandewoestijne S. \& Baguette M. 2004: Genetic population structure of the vulnerable bog fritillary butterfly. Hereditas 141: 199-206.

Vandewoestijne S., Martin T., Liegeois S. \& Baguette M. 2004: Dispersal, landscape occupancy and population structure in the butterfly Melanargia galathea. Basic Appl. Ecol. 5: 581-591.

Verovnik R., Čelik T., Grobelnik V., Šalamun A., Sečen T. \& Govedič M. 2009: Vzpostavitev monitoringa izbranih ciljnih vrst metuljev (Lepidoptera). [Monitoring of Selected Lepidoptera Species in Slovenia.] University of Ljubljana, 150 pp. [in Slovene].

Wang R., Ovaskinen O., Cao Y., Chen H., Zhou Y., Xu C. \& HANSKI I. 2011: Dispersal in the Glanville fritillary butterfly in fragmented versus continuous landscapes: comparison between three methods. Ecol. Entomol. 36: 251-260.

Weidemann H.J. 1995: Tagfalter: beobachten, bestimmen. 2. Naturbuch Verlag, Augsburg, 659 pp.

WhITE G. 2008: Program MARK. Version 5.1. $\mathrm{http} / / \mathrm{www} . \mathrm{cnr}$.colostate.edu/ gwhite

WIENS J.A. 2001: The landscape context of dispersal. In Clobert J., Danchin E., Dhondt A.A. \& Nichols J.D. (eds): Dispersal. Oxford University Press, Oxford, pp. 96-109.

Zimmermann K., BlažKová P., Čížek O., Fric Z., Hula V., Kepka P., Novotný D., Slámová I. \& KonvičKa M. 2011a: Demography of adults of the Marsh fritillary butterfly, Euphydryas aurinia (Lepidoptera: Nymphalidae) in the Czech Republic: Patterns across sites and seasons. Eur. J. Entomol. 108: $243-254$.

Zimmermann K., Fric Z., Jiskra P., KopečKová M., Vlašánek P., ZAPLetal M. \& KonviČKa M. 2011b: Mark-recapture on large spatial scale reveals long distance dispersal in the Marsh Fritillary, Euphydryas aurinia. Ecol. Entomol. 36: 499-510.

Received June 9, 2011; revised and accepted December 21, 2011 